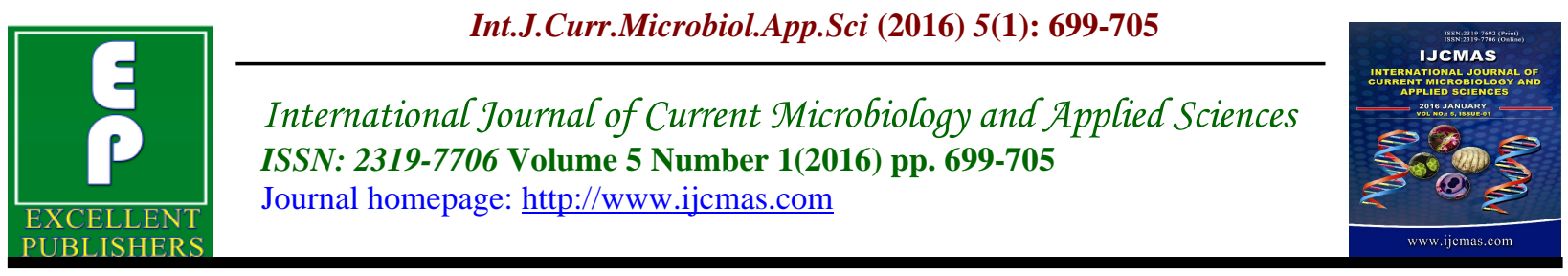

Original Research Article

hittp: ///dx.doi.org/10.20546/ijcmas.2016.501.070

\title{
Preliminary screening of Anti-cariogenic properties of selected medicinal plants against Streptococcal dental caries
}

\author{
M.D. Dinesh ${ }^{1 *}$, A. Shaheena ${ }^{1}$, K.K. Abdul Bari' ${ }^{2}$, Neethu George ${ }^{2}$ and \\ S. Meenatchisundaram ${ }^{3}$ \\ ${ }^{1}$ Department of Microbiology, GEMS Arts and Science College, \\ Ramapuram, Malappuram, India \\ ${ }^{2}$ Department of Microbiology, Pazhassiraja College, Pulpally, Wayand, India \\ ${ }^{3}$ Department of Microbiology, Nehru Arts and Science College, Coimbatore, India \\ *Corresponding author
}

A B S T R A C T

\begin{tabular}{l} 
Ke y w o r d s \\
Dental caries, \\
Plant extracts, \\
S.mutans. \\
Phytochemical \\
screening \\
\hline Article Info \\
\hline Accepted: \\
25 December 2015 \\
Available Online: \\
10 January 2016
\end{tabular}

\section{Keywords}

Dental caries,

Plant extracts,

S.mutans.

Phytochemical

screening

Accepted:

25 December 2015

10 January 2016

\section{Introduction}

Oral and Dental Health have improved enormously over the last century in the urbanized countries, but the prevalence of dental caries in the developing countries like India remains a considerable clinical problem. Tooth decay or a cavity, is a microbiological disease caused by specific type of bacteria live in human mouth.

Viridans streptococci are among the first bacteria to colonize the human mouth after birth and generally the predominant colonizing strains are $S$. mitis and S. oralis. Dental caries is a localized, transmissible, pathological infectious process that ends up in the destruction of hard dental tissue (Loesche, 1986). Streptococcus mutans and Streptococcus mitis are considered to be the main cause of dental caries.

At present various caries defensive strategies are in use like oral health education, chemical and mechanical control of plaque, use of fluorides, application of pit 
and fissure sealants etc. A lot of these approaches can be broadly effective, profitable. However behavioural or cultural barriers to their use encompass constant the epidemic of dental disease in the mouths of many people on a global level. Antibiotics are constantly in use for treating dental caries, it has been used in aspire of eradication or inhibition of biofilm in the oral cavity. Penicillin, methicillin, ampicillin, erythromycin, cephalothin, chlorhexidine digluconate and many other antibiotics have been reported to effectively prevent dental caries more than ever viridians streptococci in humans and animals. These antibiotics are never used clinically because of many adverse effects such as hypersensitivity reactions, supra infections and teeth staining. A high concentration of antibiotics causes coagulation of the intracellular constituents. As a result, the cytoplasm becomes congealed, with a resulting reduction in leakage.

These drawbacks justify further research and development of natural antibacterial plant extracts that are safe for the host or specific for oral pathogens. Herbal medicines have been important sources of products for the developing countries in treating common infectious diseases and overcome the problems of resistance and side effects of the currently available antimicrobial agents. The World Health Organisation (WHO) estimates that $80 \%$ of the people living in developing countries almost exclusively use traditional medicines. This means approximately 3300 million people use medicinal plants on a regular basis. Medicinal plants used in traditional medicine should therefore be studied for safety and efficacy. Hence in our present study we investigate the antibacterial activity of the aqueous extracts of selected indigenous medicinal plants against Streptococcal dental caries.

\section{Materials and Methods}

Bacterial strains: In our present study dental cariogens (Streptococcus mutans ((MTCC890)) were procured from M.T.C.C, Chandigarh in Lyophilized form. The Isolates were sub cultured on Todd Hewith Agar plates, bring to pure culture and maintained at $5^{\circ} \mathrm{C}$.

Collection of Medicinal plants: The medicinal plants (Muringa oliefera, Mentha arvensis, Zingiber officinale, Amaranthus dubious, Areca catechu ) were procured from Kottakal Arya Vaidya Pharmacy, Malappuram.

Preparation of medicinal plants: The plants collected are washed with water to take out the soil and dust particles. Entire plant or parts of plants were used to prepare extracts for the study and extracts were prepared by the method of Uhegbu et al. (2005) using distilled water as the solvent. $20 \mathrm{~g}$ of powdered sample of the herb was extracted by soaking in $180 \mathrm{~mL}$ of distilled water in a beaker, stirred for about $6 \mathrm{~min}$ and left overnight. Thereafter, the solution was filtered using filter paper (Whatman No. 1) and the extracts were evaporated to dryness under reduced pressure below $40^{\circ} \mathrm{C}$.

\section{Antimicrobial Assay}

Anti- cariogenic assay was performed by agar well diffusion method. The $20 \mathrm{ml}$ of sterilized Muller Hinton Agar was poured into sterile petridishes; the agar was left to set. Bacterial stock suspensions $10^{6}$ colonyforming units per $\mathrm{ml}$ were swabbed on the respective plates. In each of these plates 4 wells were made by using a sterilized $6 \mathrm{~mm}$ cork borer and the agar discs were separated. The wells were filled different extracts of $20 \mu 1,40 \mu 1,60 \mu 1,80 \mu 1$ respectively and allow diffusing of plant extract into the 
medium for about 45minutes. The plates were followed by incubated at $37 \mathrm{C}$ for $24 \mathrm{~h}$ for bacteria after which microbial growth was determined by measuring the diameter of the inhibition zone (mm) using a translucent scale. Each extract was analyzed in triplicate, the mean values are presented.

Phytochemical screening: The crude plant extract was subjected to phytochemical analysis for detecting the chemical compounds in it.

Test for Saponins - About $0.5 \mathrm{gm}$ of each plant extract was shaken with water in a test tube. Frothing, which persist on warming was taken as preliminary evidence for the presence of saponins (Kokate., 1999).

Test for Tannins - About $0.5 \mathrm{gm}$ of plant extract was stirred with $1 \mathrm{ml}$ of distilled water, filtered and a few drops of $1 \%$ ferric chloride was added to the filtrate. A blueblack, green or blue-green precipitate was taken as the evidence for the presence of tannins (Mace., 1963).

Test for Anthraquinone - About $0.5 \mathrm{gm}$ of extract was taken and $5 \mathrm{ml}$ of chloroform was added and shaken for $5 \mathrm{~min}$. The extract was filtered and filtrate was shaken with equal volume of $10 \%$ ammonia solution. A pink violet or red colour in ammoniacal layer indicates the presence of anthraquinone.

Test for Flavanoids - About $0.5 \mathrm{gm}$ of plant extracts were treated with $2 \mathrm{ml}$ of $2 \%$ sodium hydroxide solution. An intense yellow colour which turned to colourless on the drop wise addition of dilute acid indicates the presence of flavanoids. (Trease and Evans, 2002).

Test for Phenol - To the plant extracts dissolved in water equal amount of ferric chloride was added. Deep bluish green colour indicates the presence of phenol.

Salkowsky Test - $0.5 \mathrm{gm}$ of plant extract was dissolved in $2 \mathrm{ml}$ of chloroform. $2 \mathrm{ml}$ of conc. Sulphuric acid was carefully added to form a lower layer (chloroform layer). A reddish-brown colour at the interface indicates the presence of a steroidal ring. (Sofowora, 1993).

Test for Proteins - Millon's test: To $2 \mathrm{ml}$ of plant extract, added $2 \mathrm{ml}$ of Millon's reagent and observed for two minutes for the formation of white precipitate. On gentle heating which may turned to red indicates the presence of proteins in it (Rasch and Swift., 1960).

Test for Amino Acids - Ninhydrin test: To $2 \mathrm{ml}$ of plant extract, added $2 \mathrm{ml}$ of Ninhydrin reagent. Violet colour indicates the presence of amino acid / proteins in it.

Test for Sugars - About $0.5 \mathrm{ml}$ of the extract dissolved in water was taken. The volume was made upto $1 \mathrm{ml}$ with distilled water. $4 \mathrm{ml}$ of the Anthrone reagent was added. It was heated for 10 minutes in boiling water bath with lids closed. The tube was cooled rapidly. Blue black colour indicates the presence of sugars (Yemm and Wills., 1954).

Test for Reducing Sugars - To the $5 \mathrm{ml}$ of Benedict's reagent, added $2 \mathrm{ml}$ of aqueous plant extract and boiled for $5 \mathrm{~min}$ in boiling water bath. Red precipitate indicates the presence of reducing sugar.

\section{Results and Discussion}

Streptococcus mutans were procured from IMTECH, Chandigarh. The cariogens were sub-cultured on Todd Hewitt agar. Antibacterial properties of 5 different plant 
extracts were tested against Streptococcus mutans. The determination of the antibacterial activity by agar well diffusion method showed that 5 plant extracts tested exhibited antibacterial activity against Streptococcus mutans.(Table- 1\& Fig 1) Areca catechu and Muringa oliefera extracts exhibited good inhibition zones against Streptococcus mutans $(17 \mathrm{~mm}$ and $16 \mathrm{~mm})$. When the concentration of the extracts were decreased which showed slight decrease in inhibition zones.

Dental caries are the major common pathologies disturbing human kind. These circumstances are caused by plaque forming bacteria and yeast residing in the oral cavity. The common pathogens coupled with these diseases are Actinomyces, Streptococcus and Candida species etc. Streptococcus mutans associated tooth decay is one of the most common and prevalent infectious diseases in world wide. Antibiotics are generally an efficient means of treating bacterial infections, and therefore are a noticeable candidate in the treatment of dental caries.

Table.1 Antibacterial Activity of Crude Extracts of Various Medicinal Plants against S.mutans - Well Cut Method

\begin{tabular}{|c|c|c|}
\hline \multirow[t]{2}{*}{ Plant extracts } & \multirow[t]{2}{*}{ Conc. $\mu \mathrm{l} / \mathrm{ml}$} & Zone of inhibition (mm) \\
\hline & & Streptococcus mutans \\
\hline \multirow{4}{*}{ Moringa oliefera } & 80 & 16 \\
\hline & 60 & 13 \\
\hline & 40 & 10 \\
\hline & 20 & 6.0 \\
\hline \multirow{4}{*}{ Mentha arvensis } & 80 & 12 \\
\hline & 60 & 10 \\
\hline & 40 & 8.0 \\
\hline & 20 & 3.0 \\
\hline \multirow{4}{*}{ Zingiber officinale } & 80 & 14 \\
\hline & 60 & 10 \\
\hline & 40 & 7.0 \\
\hline & 20 & 3.5 \\
\hline \multirow{4}{*}{$\begin{array}{l}\text { Amaranthus } \\
\text { dubious }\end{array}$} & 80 & 16 \\
\hline & 60 & 13 \\
\hline & 40 & 10 \\
\hline & 20 & 4.0 \\
\hline \multirow{4}{*}{ Areca catechu } & 80 & 17 \\
\hline & 60 & 11 \\
\hline & 40 & 8.0 \\
\hline & 20 & 3.0 \\
\hline
\end{tabular}


Table.2 Phytochemical Result

\begin{tabular}{|l|c|c|c|c|c|}
\hline Tests & $\begin{array}{c}\text { Moringa } \\
\text { oliefera }\end{array}$ & $\begin{array}{c}\text { Mentha } \\
\text { arvensis }\end{array}$ & $\begin{array}{c}\text { Zingiber } \\
\text { officinale }\end{array}$ & $\begin{array}{c}\text { Amaranthus } \\
\text { dubious }\end{array}$ & $\begin{array}{c}\text { Areca } \\
\text { catechu }\end{array}$ \\
\hline Test for Saponin & - & - & - & + & - \\
\hline Test for Amino acids & - & - & - & - & - \\
\hline Test for proteins & - & + & + & - & - \\
\hline Test for tannins & + & + & - & - & - \\
\hline Test for Anthraquinone & - & - & - & - & - \\
\hline Test for flavanoids & + & + & + & + & + \\
\hline Test for phenols & - & - & - & - & - \\
\hline Salkowsky test & + & + & - & - & + \\
\hline Benedict test & - & - & - & - & + \\
\hline Anthrone test & + & + & + & + & + \\
\hline
\end{tabular}

Abbreviation: - + (Positive) - (Negative)

Figure.1 Comparison of Antimicrobial Activity of Crude Aqueous Extracts of Various Plants against S.Mutans

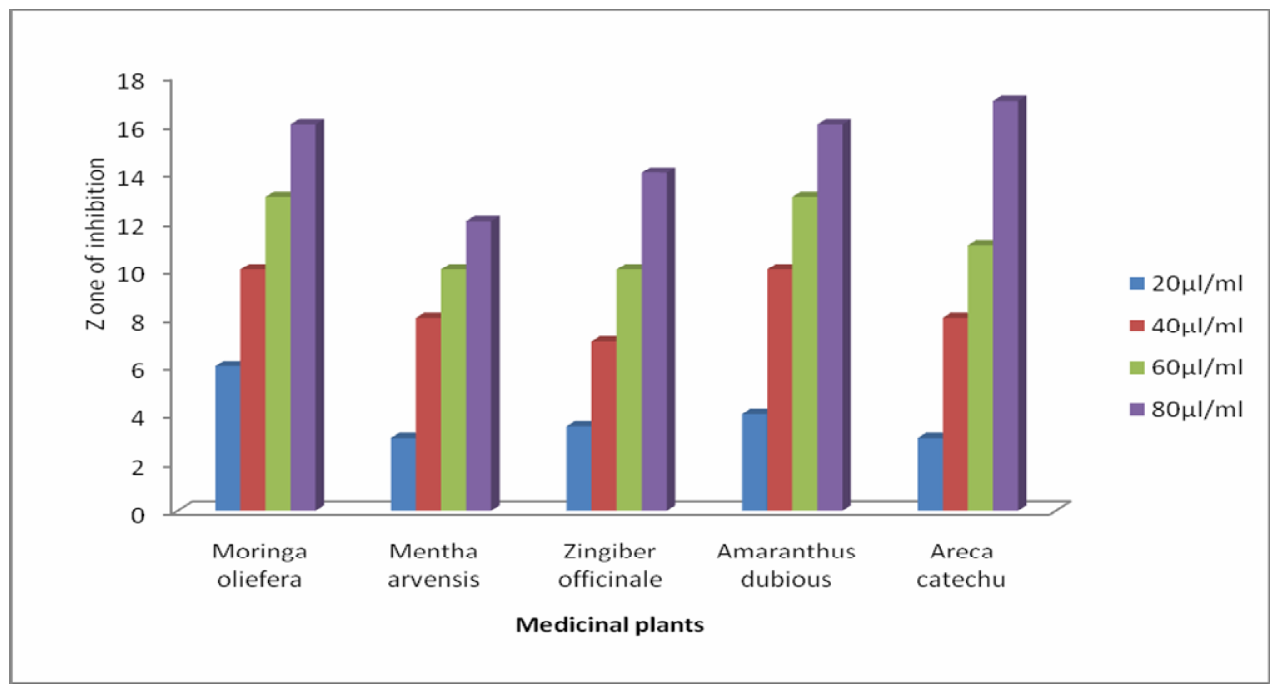

Viridans Streptococci have become increasingly resistant to antibiotics including penicillin, cephalosporin, erythromycin, and tetracycline. S. mitis is more resistant to antibiotics than other viridans Streptococci. Viridans Streptococci can transfer their resistant genes to more pathogenic Pneumococci and group A Streptococci. Among the viridans streptococci, Streptococcus mitis has been considered the species with the highest level of resistance to penicillin. Although, use of plants against the various pathogens has been long recognized, more scientific attention has been given since last 20 years. Many Indian medicinal plants are recommended for the treatment of many diseases. In our present study we investigated the inhibition properties of aqueous extract of selected indigenous medicinal plants against Streptococcal dental caries.

Dental caries causing Streptococcal sp. (S.mutans) were obtained from IMTEC, 
Chandigarh. A total of 5 aqueous extracts (crude) from 10 different plant species were investigated. Each plant extracts were tested at four different concentrations $(20 \mu 1,40 \mu 1$, $60 \mu 1$, and $80 \mu 1 / \mathrm{ml}$ ) to see their inhibitory effects against S.mutans.

The present experimental results indicate that out of 5 aqueous extracts from different plant species exhibited an antimicrobial effect against Streptococcus mutans. These results showed that the extracts from Muringa oliefera [ Muringa], Mentha arvensis [Mint], Zingiber officinale [Ginger], Amaranthus dubious [Spinach], Areca cateehu [Arechanut] possessed antimicrobial activity against Streptococcus mutans. The methanolic extract of Muringa olifera which posses compounds have inhibitory properties against oral pathogens and can used as oral medicine for dental caries (Koteswara Rao, et al., 2011). Ethanolic extracts of Mentha arvensis have the inhibitory properties against Streptococcal mutans and can be used as oral medicine. (Chaiya et al., 2013). Ethanolic extract of ginger was pronounced in cold extract than in room temperature extract. Cold method of preparation which was evaluated against room temperature was found to be more effective against oral pathogens. (Supreetha.S et al., 2011). In our present study the crude extracts of Amaranthus dubious and Areca catechu possessed antimicrobial activity against Streptococcus mutans.

The result from this preliminary study indicates that these plant extracts could be used for therapeutic purpose in case of Streptococcal dental caries. Phytochemical screening of selected plants showed the presence of Saponin, Proteins, Tannins, Flavanoids, Phenol Steroids and reducing sugars. Further investigations are needed for identification and purification of the specific antimicrobial components from these plants against Streptococcus mutans.

\section{Acknowledgment}

Our truthful thanks to the Department of Microbiology, GEMS Arts and Science College, Ramapuram, Malappuram, Kerala for given that the facilities for research work. We are extremely beholden to $\mathrm{Mr}$. Naveen Mohan (Prinicipal) Dr. Rupesh (Vice- Principal), staff members of Department of Microbiology and Biotechnology and my young scholars, Department of Microbiology Shaheena.A, Shadiya Nisha.P.T, Reema Karimbanakkal, Shareena Sherin.PK and Shana Parveen.KT for their priceless facilitate to conclude this work.

\section{References}

Chaiya. A., S. Saraya, W. Chuakul, and R. Temsiririrkkul, (2013). Screening for Dental Caries: Preventive Activities of Medicinal Plants against Streptococcus mutans. J. pharmaceutical science. 40(1), 9-7.

Kokate, C.K. $1999 . \quad$ Practical Pharmacognosy. Vallabh prakashan publication. 111-116.

Koteswara Rao, P.D. Bhaskar Rao, Ch. R. Kiran, M.R. Nadh, Y. Madhavi and T.R. Rao, (2011). In vitro antibacterial activity of Moringa oleifera against dental plaque bacteria. Journal of Pharmacy Research, 4(3): 695-697.

Loesche, W. J. (1986). Role of Streptococcus mutans in human dental decay. Microbiol. Rev. 50: 353-380.

Mace, M.E. (1963). Histochemical localization of phenols in healthy and diseased banana roots. Physiol. Plantarum. 16: 915-925.

Rasch, E and Swift, H. 1960. 
Microphotometric analysis of the cytochemical Millon reaction. $J$ Histochem Cytochem. 8: 4-17.

Sofowora, A. 1993. Screening plants for bioactive agents. In: Medicinal Plants and Traditional Medicinal in Africa, second ed., Spectrum Books Ltd., Sunshine House, Ibadan, Nigeria, pp. 134- 156.

Supreetha.S., Sharadadevi Mannur, Sequeira Peter Simon, Jithesh Jain, Shreyas Tikare, Amit Mahuli. 2011. Antifungal Activity of Ginger Extract on Candida albicans: An In-vitro Study. Journal of Dental Sciences and Research. 2
(2). 18-21.

Trease, G.E., Evans, W.C., 2002. Pharmacognosy, 15th ed. Springer, Berlin.

Uhegbu, F.O., I. Elekwa and C. Ukoha, 2005. Comparative Efficacy of crude Aqueous Extract ofMangifera indica, carica papaya and sulphadoxine pyrimethamine on the mice infested with malariaparasite in vivo. Global J. Pure Appl. Sci., 11: 399-401.

Yemm, E.W. and J. Willis. (1954). The estimation of carbohydrates in plant extracts by anthrone. Journal of Biochemical. 57(3): 508-514.

\section{How to cite this article:}

Dinesh, M.D., A. Shaheena, K.K. Abdul Bari, Neethu George and Meenatchisundaram, S. 2016. Preliminary screening of Anti-cariogenic properties of selected medicinal plants against Streptococcal dental caries. Int.J.Curr.Microbiol.App.Sci. 5(1): 699-705 http://dx.doi.org/10.20546/ijcmas.2016.501.070 